\title{
Performance of Tamarind (Tamarindus indica L.) Accessions under Dryland Conditions
}

A. Gopala Krishna Reddy, Mohammed Osman, S.K. Yadav, T.V. Prasad, K. Sreedevi Shankar, Pushpanjali, N. Jyothilakshmi, K. Salini, Vinod Kumar Singh, Jagati Yadagiri

10.18805/LR-4810

\begin{abstract}
Background: The research was conducted at the ICAR-CRIDA Hayatnagar Research Farm in Hyderabad, India. The plant material consisting of tamarind trees that were planted in 1998 with a $5 \mathrm{~m}$ spacing to improve the morphological and reproductive characteristics of elite genotypes as well as quality among the forty tamarind accessions maintained at the research farm. The experiment was started in 1998 and observations were taken over the fruiting season of 2020-2021 with forty tamarind accessions, the experiments were established in a randomized block design. The trees were identified for their consistent health and development.

Methods: Biometric observations mainly average number of flowers per inflorescence, average number of inflorescence per Branch, average number of branches per tree, average fruit weight $(\mathrm{g})$, average yield per plant $(\mathrm{kg})$, fruit, pulp, seed weights as well as shell, fibre, fruit, number of normal seeds per pod as well as damaged number of seeds per pod were recorded and analyzed statistically. Result: Significant differences among the tamarind accessions evaluated, NZB(S), Hasanur \#5, Salem 132, NTI-14 and SMG-3 recorded the highest values in all the growth, pod and yield characters. NZB(S) recorded the highest number of flowers per inflorescence (14.62) while Hasanur \# 5 recorded the highest number of inflorescence per branch (13.87). In yield attributes, NZB(S) recorded the highest average yield per plant $(\mathrm{kg})$ (15.72) followed by Hasanur \#5 (15.09), Salem 132 (14.81) and NTI-14 (14.65). The results revealed that $\mathrm{NZB}(\mathrm{S})$ showed the highest mean performance in terms of growth, yield and quality characters. The best performing accessions are being multiplied through vegetative propagation methods for planting on large scale in different locations.

Key words: Accessions, Flowering, Growth, Pod characters, Tamarind, Yield.
\end{abstract}

\section{INTRODUCTION}

The purpose of this research was to "Performance of Tamarind (Tamarindus indica L.) Accessions under Dryland Conditions". In many regions around the world, the exploration for novel high-quality and low-cost food sources is a key concern of governments and organizations concerned for food and nutrition (Balogun and Fetuga 1986).

Based on existing developments, projections indicate a gap between human population and food supply (Vijayakumari et al. 1997). As a consequence, research efforts are being focused on finding and analysing underutilised crops that have been neglected to the disadvantage of human development as future food crops (Egbe and Akinyele 1990; Adekunle and Ojerinde 2004).

Tamarind is a member of the dicotyledonous Leguminosae family, which is the third biggest flowering plant family with 727 genera and 19,327 species (Lewis et al., 2005). The term tamarind comes from the the Arabic word "Tamar-E Hind" meaning "Date of India". It is almost found throughout the tropics and sub-tropics of the world and has naturalized at many places particularly in India, South East Asia, Tropical America, the Pacific Islands and the Caribbean. The Asian countries, such as India and Thailand, are the primary producers. Tamarind popularly known as Imli is one of the auspicious, versatile tree in the Indian subcontinent and particularly abundant in the States of Madhya Pradesh, Bihar andhra Pradesh, Telangana, Chhattisgarh, Karnataka, Tamil Nadu and West Bengal (Singh et al., 2007). It is a diploid species with $2 n=26$
Department of Horticulture, ICAR-Central Research Institute for Dryland Agriculture, Hyderabad-500 059, Telangana, India.

Corresponding Author: A. Gopala Krishna Reddy, Department of Horticulture, ICAR-Central Research Institute for Dryland Agriculture, Hyderabad-500 059, Telangana, India.

Email: Agk.Reddy@icar.gov.in

How to cite this article: Reddy, A.G.K., Osman, M., Yadav, S.K., Prasad, T.V., Shankar, K.S., Pushpanjali, Jyothilakshmi, N., Salini, K., Singh, V.K. and Yadagiri, J. (2022). Performance of Tamarind (Tamarindus indica L.) Accessions under Dryland Conditions. Legume Research. DOI: 10.18805/LR-4810.

Submitted: 08-10-2020 Accepted: 04-02-2022 Online: 04-03-2022

chromosomes (Purseglove, 1987). India is the world's largest producer of tamarind and it is estimated that 300,000 tons are produced annually. Tamarind is an important cash crop of India and enjoys sixth position in terms of export earnings. Tamarind tolerates high $\mathrm{pH}$ and is well suited to wastelands, drylands, saline and sodic soils. The trees act as windbreak in many areas and also suitable for drought prone areas. Tamarind thrives in a tropical climate with hot, dry summers and moderate winters. It can withstand drought but is prone to frost. Tamarind can be grown in almost all types of soil even on poor and margin soils, since; its lifespan is long, deep loamy soils with adequate soil moisture holding capacity is ideal. A typical fruit contains about $55 \%$ pulp, $34 \%$ seeds and $11 \%$ shell and fibre on weight basis 
(Rao et al., 2001; De Caluwe et al., 2010). Due to the obvious large amount of fruit produced, processing firms now have a plenty of raw material to work with. Fruit's excellent flavour, nutritional content and therapeutic properties indicate that it has a high potential for processing into value-added goods with a long shelf life. Processing into value-added products is one means of preserving this commodity and improving its use for human health. Soups, jams, chutneys, sauces and juices all use the edible pulp of ripe fruit as a flavouring component (Isholoa et al. 1990). The tamarind fruit pulp has the most tartaric acid (8-18\%) of any natural source. Moreover, pulp is the only material used for culinary purposes (Balan et al., 2017). Hence the present investigation on performance of tamarind (Tamarindus indica L.) accessions under dryland conditions was carried out at Hayatnagar Research Farm, ICAR-CRIDA.

\section{MATERIALS AND METHODS}

The study was conducted at Hayatnagar Research Farm, ICAR-CRIDA Hyderabad, India, from 2020 to 2021 with the objective of recording the flowering and fruiting characteristics of elite genotypes as well as quality among the forty tamarind accessions kept at the research farm (Fig 1). The field trail was established in 1998 and evaluated during fruiting season of 2020-2021 (22 years aged plants). Three replications and 40 genotypes were used for the experiment, which has been arranged in a randomised block design viz., Hasanur \#3, Hasanur \#5, Vellore \#2, Vellore \#29, Salem 132, Urigam CT 164, Urigam CT 112, PKM-1, Urigam, Vantoor, Sweet, Red, NZB (S), KRMR, PKM (Red), Prathistan, HYD (Local), Salem Red, Salem Blue, NTI-14, NTI-32, NTI-39, NTI-42, NTI-56, NTI-60, NTI-73, NTI-75, NTI-76, NTI-82, NTI-84, NTI-85, NTI-86, CMK-5, CMK-6, CMK-7, SMG-3, SMG-4, SMG-7, SMG-13 and BDM-3. The findings of eleven quantitative characters' observations viz., number of flowers per inflorescence, number of inflorescence per branch, number of fruits per branch, fruit weight $(\mathrm{g})$, pulp weight per fruit $(g)$, seed weight per fruit $(g)$, shell weight per fruit $(\mathrm{g})$, fibre weight per fruit $(\mathrm{g})$, total number of seeds per pod (normal and damaged) were taken account of for all of the genotypes selection of study. For recording horticultural traits, five observations of each genotype were chosen at random from each replication. At a $5 \%$ level of probability, the significance of the mean was assessed using the Critical Differences (CD) test (Panse and Sukhatme, 1985).

\section{RESULTS AND DISCUSSION}

Development of high yielding varieties of crop/trees requires information about the nature and magnitude of variability present in the available accessions in phenotypic characters that are connected with yield. The morphological parameters of forty tamarind accessions are described in Tables 1 and 2. Significant differences among forty tamarind accessions were observed. The findings revealed that among forty tamarind accessions, NZB (S) recorded the highest values in case of pod and yield characters. NZB (S) accession recorded the highest average number of flowers per inflorescence (14.62) which was the highest among the forty tamarind accessions followed by Salem 132 (13.61), Hasanur \#5 (13.25) and NTI-75 (12.91) while it was the lowest in SMG-7 (8.18) followed by Urigam CT 164 (8.47), NTI-82 (8.63) and NTI-42 (9.12)

In case of average number of inflorescence per branch Hasanur \#5 accession recorded the highest value of 13.87 followed by NZB (S) (12.94), NTI-14 (12.72) and PKM (Red) (12.61) and the lowest was noticed in SMG-7(7.4) followed by Urigam CT 164 (7.62), NTI - 82 (7.91) and NTI - 42 (8.27). Average number of branches per tree Hasanur \#5 accession recorded the highest value of 6.11 followed by NZB (S) (5.94), Salem 132 (5.92) and NTI - 14 (5.91) and the lowest was noticed in SMG-7(3.21) followed by Urigam CT 164 (3.57), NTI - 82 (3.64) and NTI - 42 (3.68). In the case of average fruit weight $(\mathrm{g})$, NZB (S) accession recorded the highest value of 19.24 followed by Salem 132 (19.08), Hasanur \#5 (18.59) and PKM (Red) (16.34) and the lowest was noticed in CMK-6 (8.82)followed by KRMR (9.05), Urigam CT 164 (9.37) and Red (9.42). Average yield per plant $(\mathrm{kg})$ NZB (S) accession recorded the highest value of 15.72 followed by Hasanur \#5 (15.09), Salem 132 (14.81) and NTI-14 (14.65) and the lowest was noticed in SMG-7

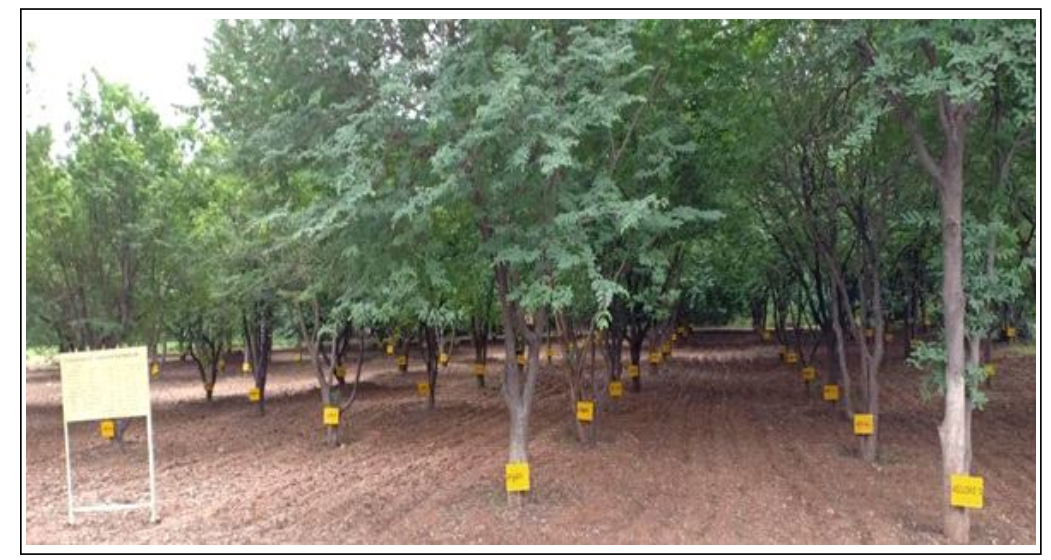

Fig 1: General view of the experimental field. 
Performance of Tamarind (Tamarindus indica L.) Accessions under Dryland Conditions

Table 1: Evaluation of 40 tamarind accessions for flowering, fruiting and yield characters.

\begin{tabular}{|c|c|c|c|c|c|}
\hline Variety & $\begin{array}{l}\text { Ave. no. of flowers/ } \\
\text { inflorescence }\end{array}$ & $\begin{array}{c}\text { Ave. no. of } \\
\text { inflorescence/Branch }\end{array}$ & $\begin{array}{l}\text { Ave. no. of } \\
\text { branches/tree }\end{array}$ & $\begin{array}{l}\text { Ave. fruit } \\
\text { weight }(g)\end{array}$ & $\begin{array}{l}\text { Ave. Yield/ } \\
\text { plant }(\mathrm{kg})\end{array}$ \\
\hline Hasanur \#3 & 11.49 & 9.73 & 5.14 & 9.42 & 12.27 \\
\hline Hasanur \#5 & 13.25 & 13.87 & 6.11 & 18.59 & 15.09 \\
\hline Vellore\#2 & 10.17 & 11.41 & 5.13 & 10.64 & 12.36 \\
\hline Vellore\#29 & 0 & 0 & 0 & 0 & 0 \\
\hline Salem 132 & 13.61 & 10.96 & 5.92 & 19.08 & 14.81 \\
\hline Urigam CT 164 & 8.47 & 7.62 & 3.57 & 9.37 & 4.83 \\
\hline Urigam CT 112 & 10.46 & 8.74 & 3.76 & 10.13 & 7.92 \\
\hline PKM- 1 & 11.81 & 12.35 & 5.66 & 12.79 & 13.54 \\
\hline Urigam & 12.17 & 11.41 & 4.65 & 11.26 & 10.54 \\
\hline Vantoor & 10.92 & 9.28 & 3.84 & 13.92 & 8.79 \\
\hline Sweet & 12.67 & 10.81 & 4.73 & 12.89 & 11.17 \\
\hline Red & 12.15 & 11.36 & 4.82 & 9.45 & 11.51 \\
\hline NZB (S) & 14.62 & 12.94 & 5.94 & 19.24 & 15.72 \\
\hline KRMR & 12.34 & 11.77 & 5.81 & 9.05 & 13.94 \\
\hline PKM (Red) & 11.21 & 12.61 & 4.92 & 16.34 & 12.13 \\
\hline Prathistan & 12.87 & 10.48 & 4.79 & 14.50 & 11.38 \\
\hline HYD (Local) & 10.93 & 9.69 & 3.95 & 12.82 & 8.84 \\
\hline Salem Red & 0 & 0 & 0 & 0 & 0 \\
\hline Salem Blue & 0 & 0 & 0 & 0 & 0 \\
\hline NTI-14 & 11.51 & 12.72 & 5.91 & 14.26 & 14.65 \\
\hline NTI-32 & 10.34 & 9.15 & 3.82 & 13.01 & 8.26 \\
\hline NTI-39 & 11.67 & 10.86 & 4.53 & 9.74 & 9.41 \\
\hline NTI-42 & 9.12 & 8.27 & 3.68 & 12.52 & 6.26 \\
\hline NTI-56 & 10.36 & 8.92 & 3.81 & 14.69 & 8.47 \\
\hline NTI-60 & 11.38 & 12.54 & 5.17 & 15.47 & 12.64 \\
\hline NTI-73 & 0 & 0 & 0 & 0 & 0 \\
\hline NTI-75 & 12.91 & 10.63 & 4.86 & 12.47 & 11.86 \\
\hline NTI-76 & 0 & 0 & 0 & 0 & 0 \\
\hline NTI-82 & 8.63 & 7.91 & 3.64 & 12.47 & 5.74 \\
\hline NTI-84 & 11.92 & 10.64 & 4.62 & 10.54 & 10.23 \\
\hline NTI-85 & 12.74 & 11.46 & 5.21 & 13.86 & 13.17 \\
\hline NTI-86 & 12.41 & 10.81 & 4.67 & 15.31 & 10.72 \\
\hline CMK-5 & 11.36 & 10.18 & 4.52 & 12.49 & 9.33 \\
\hline CMK-6 & 12.28 & 11.37 & 4.78 & 8.82 & 11.29 \\
\hline CMK-7 & 11.64 & 12.46 & 5.68 & 14.13 & 13.62 \\
\hline SMG-3 & 12.56 & 11.94 & 5.86 & 12.79 & 14.23 \\
\hline SMG-4 & 12.71 & 11.29 & 5.64 & 11.31 & 13.38 \\
\hline SMG-7 & 8.18 & 7.45 & 3.21 & 9.82 & 2.47 \\
\hline SMG-13 & 11.46 & 12.16 & 4.93 & 11.53 & 11.92 \\
\hline BDM-3 & 12.31 & 11.52 & 5.21 & 10.08 & 12.83 \\
\hline S.E. & 1.30 & 1.11 & 0.47 & 0.92 & 0.79 \\
\hline CD (0.05\%) & 2.59 & 2.22 & 0.93 & 1.84 & 1.58 \\
\hline
\end{tabular}

(2.47) followed by NTI-82 (5.74) and NTI-42 (6.26) and Urigam CT 112 (7.92).

The fruit characters such as pulp weight per fruit, seed weight per fruit, shell weight per fruit, fibre weight, total number of seeds per pod and normal number of seeds per pod number are presented in Table 2. Significant differences were observed among the forty tamarind accessions evaluated. The findings revealed that pulp weight per fruit ranged from 9.27 to $3.46 \mathrm{~g}$. The highest pulp weight per fruit recorded in NZB (S) accessions $(9.27 \mathrm{~g})$ followed by Hasanur \#5 (9.24 g), Vantoor (8.93) and Salem-132 (8.72). The lowest shell weight was found in CMK-6 of $3.46 \mathrm{~g}$ followed by Urigam CT 164 (3.53), NTI-39 (3.76) and Hasanur \#3 (3.83). Seed weight per fruit ranged from 6.52 
Performance of Tamarind (Tamarindus indica L.) Accessions under Dryland Conditions

Table 2: Evaluation of 40 tamarind accessions for pod characters.

\begin{tabular}{|c|c|c|c|c|c|c|c|}
\hline Variety & $\begin{array}{l}\text { Pulp wt/ } \\
\text { fruit (g) }\end{array}$ & $\begin{array}{l}\text { Seed wt/ } \\
\text { fruit (g) }\end{array}$ & $\begin{array}{l}\text { Shell wt/ } \\
\text { fruit (g) }\end{array}$ & $\begin{array}{l}\text { Fibre wt / } \\
\text { fruit }(g)\end{array}$ & $\begin{array}{l}\text { Total seed/ } \\
\text { Pod (no's) }\end{array}$ & $\begin{array}{l}\text { Normal seed } \\
\text { /pod (no's) }\end{array}$ & $\begin{array}{c}\text { Damaged } \\
\text { seed/pod (no's) }\end{array}$ \\
\hline Hasanur \#3 & 3.83 & 3.15 & 2.12 & 0.32 & 7.23 & 6.61 & 1.23 \\
\hline Hasanur \#5 & 9.24 & 6.52 & 2.32 & 0.51 & 9.27 & 8.45 & 0.82 \\
\hline Vellore \#2 & 4.81 & 3.22 & 2.36 & 0.25 & 8.72 & 7.83 & 0.89 \\
\hline Vellore \#29 & 0 & 0 & 0 & 0 & 0 & 0 & 0 \\
\hline Salem 132 & 8.72 & 6.42 & 3.86 & 0.24 & 8.54 & 7.48 & 1.06 \\
\hline Urigam CT 164 & 3.53 & 3.22 & 2.15 & 0.47 & 7.41 & 7.34 & 1.51 \\
\hline Urigam CT 112 & 4.63 & 2.61 & 2.36 & 0.53 & 6.83 & 5.71 & 1.12 \\
\hline PKM- 1 & 5.74 & 4.64 & 1.93 & 0.48 & 7.34 & 6.37 & 0.97 \\
\hline Urigam & 4.38 & 3.73 & 2.72 & 0.43 & 8.93 & 7.68 & 1.25 \\
\hline Vantoor & 8.93 & 5.76 & 3.67 & 0.70 & 8.38 & 7.45 & 0.93 \\
\hline Sweet & 5.85 & 3.82 & 2.84 & 0.38 & 8.56 & 7.31 & 1.25 \\
\hline Red & 4.26 & 2.59 & 2.38 & 0.47 & 6.97 & 5.81 & 1.16 \\
\hline NZB (S) & 9.27 & 5.32 & 2.21 & 0.22 & 10.78 & 9.38 & 0.62 \\
\hline KRMR & 4.41 & 2.63 & 1.63 & 0.38 & 6.28 & 5.38 & 0.9 \\
\hline PKM (Red) & 5.92 & 4.21 & 2.32 & 0.54 & 8.37 & 7.21 & 1.16 \\
\hline Prathistan & 6.27 & 4.26 & 3.25 & 0.72 & 10.54 & 6.18 & 1.16 \\
\hline HYD (Local) & 5.87 & 4.13 & 2.37 & 0.45 & 9.78 & 8.24 & 1.54 \\
\hline Salem Red & 0 & 0 & 0 & 0 & 0 & 0 & 0 \\
\hline Salem Blue & 0 & 0 & 0 & 0 & 0 & 0 & 0 \\
\hline NTI-14 & 5.96 & 5.21 & 2.51 & 0.58 & 8.87 & 7.51 & 1.36 \\
\hline NTI-32 & 5.72 & 4.68 & 2.18 & 0.43 & 8.14 & 6.93 & 1.21 \\
\hline NTI-39 & 3.76 & 3.03 & 2.57 & 0.38 & 9.47 & 7.93 & 1.53 \\
\hline NTI-42 & 4.83 & 4.39 & 2.49 & 0.81 & 7.65 & 6.37 & 1.28 \\
\hline NTI-56 & 7.25 & 4.74 & 2.13 & 0.57 & 7.48 & 6.35 & 1.13 \\
\hline NTI-60 & 6.13 & 5.58 & 3.27 & 0.49 & 7.63 & 6.74 & 0.89 \\
\hline NTI-73 & 0 & 0 & 0 & 0 & 0 & 0 & 0 \\
\hline NTI-75 & 5.24 & 4.72 & 1.98 & 0.53 & 5.89 & 4.93 & 0.96 \\
\hline NTI-76 & 0 & 0 & 0 & 0 & 0 & 0 & 0 \\
\hline NTI-82 & 5.83 & 4.23 & 1.84 & 0.57 & 6.94 & 5.64 & 1.3 \\
\hline NTI-84 & 4.79 & 4.26 & 1.17 & 0.32 & 7.48 & 6.25 & 1.23 \\
\hline NTI-85 & 6.42 & 4.23 & 2.83 & 0.38 & 7.57 & 6.26 & 1.31 \\
\hline NTI-86 & 7.37 & 4.77 & 2.63 & 0.54 & 5.83 & 4.75 & 1.08 \\
\hline CMK-5 & 5.83 & 4.13 & 1.88 & 0.65 & 8.49 & 7.14 & 1.35 \\
\hline CMK-6 & 3.46 & 3.22 & 1.76 & 0.38 & 7.63 & 6.78 & 0.85 \\
\hline CMK-7 & 6.48 & 4.32 & 2.79 & 0.54 & 7.34 & 6.26 & 1.08 \\
\hline SMG-3 & 5.79 & 4.24 & 2.37 & 0.39 & 8.67 & 7.43 & 1.24 \\
\hline SMG-4 & 5.86 & 3.21 & 1.81 & 0.43 & 5.49 & 4.27 & 1.22 \\
\hline SMG-7 & 3.83 & 3.51 & 2.11 & 0.37 & 7.58 & 6.46 & 1.12 \\
\hline SMG-13 & 4.68 & 4.07 & 2.14 & 0.64 & 6.87 & 5.84 & 1.03 \\
\hline BDM-3 & 4.43 & 2.96 & 1.98 & 0.71 & 8.74 & 7.49 & 1.25 \\
\hline S.E. & 0.94 & 0.64 & 0.35 & 0.06 & 0.76 & 0.91 & 0.18 \\
\hline CD $(0.05 \%)$ & 1.88 & 1.28 & 0.70 & 0.1327 & 1.52 & 1.82 & 0.37 \\
\hline
\end{tabular}

to $2.59 \mathrm{~g}$ and the highest was recorded in Hasanur \#5 $(6.52 \mathrm{~g})$ followed by Salem 132 (6.42), Vantoor (5.76) and NTI-60 (5.58) and the lowest in Red $(2.59 \mathrm{~g})$ followed by Urigam CT 112 (2.61), KRMR (2.63) and BDM-3 (2.96), Shell weight per fruit ranged from 3.86 to $1.17 \mathrm{~g}$ and the highest was recorded in Salem 132 (3.86 g) followed by and Vantoor (3.67 g), NTI -60 (3.27 g) and Prathistan (3.25). The lowest pulp weight was observed in NTI-84 $(1.17 \mathrm{~g})$ followed by
KRMR (1.63 g), CMK-6 (1.70 g) and SMG-4 (1.81). Similarly, fibre weight per fruit ranged from 0.81 to $0.22 \mathrm{~g}$ and the highest was recorded in NTI-42 (0.81) followed by Vantoor (0.73), Prathistan (0.72) and BDM-3 (0.71) the lowest was noticed in NZB (S) (0.22) followed by Salem $132(0.24)$, Vellore\#2 (0.25) and NTI-84 (0.32). Similar, such variations in fruit characteristics were observed in tamarind by Divakara (2008a) and Nandini et al. (2011). 
Regarding seed characters, accession NZB (S) recorded the highest total number of seeds per pod (10.78) which was the highest among forty tamarind accessions followed by Prathistan (10.54), Hyd (local) (9.73) and NTI-39 (9.47). The lowest total number of seeds per pod was noticed in SMG-4 accession (5.49) followed by NTI -86 (5.83), NTI -75 (5.89) and SMG-13 accession (6.87). The highest normal number of seeds per pod was recorded in NZB (S) (9.38) followed by Hasanur \#5 (10.54), Hyd (local) (8.24) and NTI -39 (7.93) and the lowest was noticed in SMG-4 (4.27) followed by NTI -86 (4.75), NTI -75 (4.93) and SMG-13 accession (5.84). The highest number of seeds damaged per pod was recorded in Hyd (local) (1.54) followed by NTI-39 (1.53), Urigam CT 164 (1.51) and NTI-14 (1.36) and the lowest in NZB (S) (0.62) followed by Hasanur \#5 (0.82), CMK-6 (0.85) and NTI-60 (0.89). Wide variations were noticed among the different accessions with respect to yield contributing traits and this may be due to their genotypic differences. In addition, age of the tree is also an important factor which influences the yield.

\section{CONCLUSION}

Among the forty tamarind accessions evaluated, NZB (S), Hasanur \#5, Salem 132, NTI-14 and SMG-3 recorded the highest values in all the growth, pod and yield characters. NZB (S) recorded the highest number of flowers per inflorescence (14.62), Hasanur \#5 recorded the highest number of inflorescence per branch (13.87). NZB(S) recorded the highest average fruit weight $(g)$ (19.24), pulp weight per fruit (g) (9.27), Total seed per Pod (no's) (10.78), Normal seed/pod (no's) (9.38) compare to remaining all tamarind accessions and also $\mathrm{NZB}(\mathrm{S})$ recorded the lowest Fibre weight per fruit (g) (0.22), Damaged seed per pod (no's) (0.62). In case of yield characters, NZB(S) recorded the highest average yield per plant $(\mathrm{kg})$ (15.72) followed by Hasanur \#5 (15.09), Salem 132 (14.81) and NTI - 14 (14.65). Based on performance, yield and quality parameters, NZB (S), Hasanur \#5, Salem 132, NTI-14 and SMG-3 accessions have been identified as the most promising in dryland situation representing semi-arid tropics and their further evaluation on large scale is recommended.

Conflict of interest: None.

\section{REFERENCES}

Adekunle V.A.J., Ojerinde, O.V. (2004). Food potentials of some indigenous wild fruit in lowland rain forests ecosystems of south west Nigeria. Journal of Food Technology 2. 125-130.

Balan, A., Krishnan, A., Josna, K., Stephen, L. and Shivaji, K.P. (2017). Identification of a mechanism for mechanical deseeding of tamarind. Int. Journal of Engineering Research and Application. 7(12): 1-4.

Balogun, A.M., Fetuga, B.L. (1986) Chemical composition of some under-exploited leguminous crop seeds in Nigeria. Journal of Agricultural and Food Chemistry 34. 189-192.

De Caluwe, E., Halamov, K., Van Damme, P. (2010). Tamarind (Tamarindus indica L.): A Review of Traditional Uses, Phytochemistry and Pharmacology. In: African Natural Plant Products: Discoveries and Challenges in Quality Control. [Juliani H.R., et al. (eds)], American Chemical Society, ACS Symposium Series 1021 Washington DC. US: p. 5-110.

Divakara, B.N. (2008). Variation and character association for various pod traits in Tamarindus indica L. Indian Forester. 134: 687-696.

Egbe, I.A., Akinyele, I.O. (1990). Effect of cooking on the antinutritional factors of lima beans (Phaseolus lunatus). Food Chemistry. 35: 81-88.

Isholoa, M.M., Agbaji, E.B., Agbaji, A. (1990). A chemical study of Tamarindus indica L. fruits grown in Nigeria. J. Sci. Food Agric. 51: 141-143.

Lewis, G. Schrire, B. Mackinder, B. and Lock, M. (eds.) (2005). Legumes of the World. Royal Botnaic Gardens. Kew.

Nandini, R., Singh, T.R., Dhanapal, G.N. (2011). Morphometric and molecular diversity studies in Tamarind (Tamarindus indica Linn.) population. J Plant Mol. Biol. Biotechnol. 2(2): 26-33.

Nas, S. (1979). Tropical Legumes: Resources for the Future, Washington DC. 117-121.

Panse, V. and Sukhatme, P.V. (1985). Statistical Methods for Agricultural Workers. ICAR, New Delhi.

Purseglove, J.W. (1987). Tropical crops. Dicotyledons, Longria, Science and Technology. $204-206$.

Rao, Y.S. and Mary Mathew, K. (2001). Tamarind, in Peter KV (ed.), Handbook of Herbs and Spices. Vol. 1. Woodhead, Cambridge. 287-96.

Singh, D., Wangchu, L. and Mood, S.K. (2007). Processed products of tamarind. Natural Product Radiance. 6(4): 315-317.

Vijayakumari, K., Siddhuraju, P., Janardhanan, K., (1997). Chemical composition, amino acid content and protein quality of the little-known legume Bauhinia purpurea L. Journal of the Science of Food and Agriculture. 73: 279-286. 